\title{
Students’ Evaluation of Professional Personality Competencies of Physical Education Teachers Working in High Schools
}

\author{
Erdal Demir \\ Canakkale Onsekiz Mart University, Çanakkale, Turkey
}

\begin{abstract}
The purpose of the study is to examine the relationship between professional personality competencies of physical education teachers working in high schools and gender, school type, and class variables of students. The study was organised according to the screening model. The study was carried out in a total of 17 schools, 16 state and one private, connected to the Ministry of National Education located in Canakkale province, with 1,254 high school students attending in the academic year 2013-2014. Of the research group, 52.2\% were female students and 47.8\% were male students. The Physical Education Teacher Professional Personality Competence Scale-Student (PET PPCS-Student) was used as the data collection tool in the study. There were significant differences found in all subcomponents according to school type and class variables of the participants $(p<0.05)$.
\end{abstract}

Keywords: physical education, competence, physical education teacher, high school

\section{Introduction}

The concept of competence is used as the equivalent of standard and quality. Teacher competence is a concept which is used to list in detail the attitudes, knowledge, and skills teachers should have (Turkish Education Association (TED), 2009). The answers to Wilson's (2011) question of "How can we improve teacher competencies?" is stated in his study as providing suitable candidates for teacher competencies, keeping teachers who are better at their duties, entering lessons well prepared, providing good working conditions, and providing quality professional development.

Stronge (2007) explained the general competence of teachers in six components: valuing students, respect for student personality and equality, social interaction, professional enthusiasm and motivation, job attitudes, and reflective interaction.

Buyuknacar (2008) defined teachers' professional personality competencies as information which is expected to be known in their field which is specific to the individual's occupational group and features by which professional knowledge is evaluated.

Competencies of physical education teachers are explained as required knowledge, understanding, skills, and attitudes which are needed by physical education teachers in order to perform duties and responsibilities (Unlu, Sunbul, \& Aydos, 2008).

Physical education lessons improve students' leadership skills and self-confidence, increase love and respect for the environment and themselves, help in obeying school and class rules, and provide balanced eating habits (Camlıca, 2008). Physical education lessons were seen as an enjoyable and fun lesson by secondary

Erdal Demir, Ph.D., assistant professor, School of Physical Education and Sport, Canakkale Onsekiz Mart University. 
school and high school students (Tannehil \& Zakrajsek, 1993). Also, in research conducted by Sisko and Demirhan (2002) and Gullu (2007), attitudes of primary and secondary school students toward physical education classes were found to be positive.

To make students love the lessons, the teacher should be more effective than the lesson (Eken, 2008). There was a positive relationship seen between success of the students who participated in science and mathematics courses and teacher competence (Monk, 1994). Darling-Hammond (1999) obtained similar results about the relationship between teacher quality and student success in his research. In the study of Lee, Robinson, and Sebastian (2007), in which education quality of different lessons were evaluated according to views of teachers and students, it was found that teachers have a significant impact on improving the quality of teaching. In education, one of the many variables affecting student success is the teacher (Centra \& Pootter, 1980).

One of the items adding quality to physical education lessons is the physical education teacher. Professional competence of physical education teachers is very important in order to increase quality standards in physical education lessons (Atencio, Jess, \& Dewar, 2012). Yaylacı (2012) formulated "Quality physical education lesson = Quality physical education teacher” for quality physical education lessons.

According to Sacl, Bulca, Demirhan, and Kangalgil’s (2009) personal qualifications of physical education teachers, they should be open to criticism, understand students in all topics, have a broad perspective, patient, self-confident, have the ability to improvise, and be creative and compassionate. There are 10 components necessary for quality physical education lessons, which are teachers, students, program, leadership, learning for life, community, learning, pedagogy, research, and assessment (Pill, 2004).

In light of these explanations, the aim of the research is to determine how professional personality competencies of physical education teachers working in high schools are perceived by 9th, 10th, and 11th grade students.

\section{Method}

\section{Participants and Procedure}

Comparisons were made in the study of the professional personality competencies of physical education teachers according to gender, age, and school type of high school students. Therefore, the research was carried out using a relational screening model which is one of the general screening models.

The research included state and private high schools connected to the Ministry of National Education in Canakkale. In the 2013-2014 academic year when the research was carried out, there were 23,069 students from a total of 85 high schools, 84 state and one private, within Canakkale, which comprised the population of the research.

The research group consisted of 1,254 students who are in the 9th, 10th, and 11th grades of 16 state and one private high schools. The 12th grade high school students were excluded from the research in consideration of their preparation for the university entrance exam. The research was conducted in 17 schools: five from the centre of Canakkale, one from Ayvacık, two from Biga, two from Bayramic, one from Lapseki, one from Ezine, two from Can, one from Yenice, and two from Gelibolu. Variables which can affect the research, such as accessibility, school administration, and approach of the teachers, were taken into account by random selection. To select the students, 25 students were chosen randomly from each 9th, 10th, and 11th grade class, by considering that each student in each class had an equal chance of being included in the selection process. The 
classes with insufficient numbers were increased by adding students from other classes.

While $52.2 \%(N=654)$ of the students were female, $47.8 \%(N=600)$ of them were male students. Of the research group, 33.1\% $(N=415)$ consisted of 9th graders, 33.7\% $(N=422)$ were 10th graders, and 33.2\% $(N=417)$ were 11th graders. Of the students, $94 \%(N=1,179)$ were in state schools and $6 \%(N=75)$ were studying in private schools.

\section{Instruments}

In the research, to evaluate the professional personality competencies of their physical education teachers, high school students were administered the Physical Education Teacher Professional Personality Competence Scale-Students (PET PPCS-Student). The PET PPCS-Student is based on the Professional Personality Scale developed by Buyuknacar (2008) and has been updated by adaptation for physical education teachers by Demir (2012). The PET PPCS-Student consists of four subcomponents and 60 items. The scale is Likert-type and students have five answer choices for each item. These options are rated on the scale as: $1=$ "Strongly disagree", 2 = "Disagree", 3 = "Neutral", 4 = "Agree", and 5 = "Strongly agree”. The value ranges of the scale are rated as: 1-1.99 = "Completely inadequate", 2-2.99 = "Partly inadequate", 3-3.39 = "Partly adequate", and 4-5 = "Completely adequate”. Participants answered the scale by valuing from 1 to 5 . Gender, class, and school type of students are also included in the scale. PET PPCS-Student has four subcomponents, which are professional enthusiasm and dedication, respect for human dignity and justice, motivational interaction, and reflective interaction.

The overall reliability coefficient (Cronbach's alpha) of the scale is 0.98 and it is in the high reliability category (Demir, 2012).

\section{Data Analysis}

Data analysis was completed using Statistical Package for the Social Sciences (SPSS) Version 16.0. Mann-Whitney $U$-test, Analysis of Variance (ANOVA), and independent group $t$-tests were performed with the intent of determining differentiation status of frequency and percentage values and factor points according to school type, gender, and class of the students. Significance level was taken as 0.05 .

\section{Ethical Consideration}

Ethical approval was obtained from the Ethics Committee of the Health Sciences Institute (Date: 10/04/2014, No.: 050.99-84). Permission for the schools to participate in the study was obtained from Canakkale Provincial Directorate of National Education (Date: 13/03/2014, No: 60305806/1083884). Students were informed about the study prior to agreeing to participate and were assured that their participation in the study was entirely voluntary.

\section{Findings}

The results of the highest and lowest average points of the application of the PET PPCS-Student to participants are shown in Table 1. The highest average points of the PET PPCS-Student $(M=4.36)$ were for the item "They care that honesty and trust form the basis of our communication in school". The item which had the lowest average points $(M=3.46)$ is "They do not criticise a student who has negative behaviour in front of the class". The items of the scale were evaluated as "Partly adequate" or "Completely adequate" by the study group. 
Table 1

Descriptive Statistics of PET PPCS-Student

\begin{tabular}{|c|c|c|c|c|c|}
\hline Scale items & $N$ & Min. & Max. & $M$ & $S D$ \\
\hline 2. They care that honesty and trust form the basis of our communication in school & 1,254 & 1.00 & 5.00 & 4.36 & 0.992 \\
\hline 5. They do not criticise a student who has negative behaviour in front of the class & 1,254 & 1.00 & 5.00 & 3.46 & 1.426 \\
\hline
\end{tabular}

The average points for the subcomponents of the PET PPCS-Student are shown in Table 2. As a result of assessment of the subcomponents of the scale, professional enthusiasm and dedication was evaluated as “completely adequate” with the highest average points $(M=4.05)$. Respect for human dignity and justice subcomponent had the lowest average points $(M=3.85)$ and was evaluated as "Partly adequate”. Reflective interaction and motivational interaction subcomponents were also evaluated as "Completely adequate” by the study group.

Table 2

Descriptive Statistics of Subcomponents of PET PPCS-Student

\begin{tabular}{llllll}
\hline Professional personality competencies & $N$ & Min. & Max. & $M$ & $S D$ \\
\hline Motivational interaction & 1,254 & 1.00 & 5.00 & 4.02 & 0.901 \\
Professional enthusiasm and dedication & 1,254 & 1.00 & 5.00 & 4.05 & 0.889 \\
Human dignity and justice & 1,254 & 1.00 & 5.00 & 3.85 & 1.002 \\
Reflective interaction & 1,254 & 1.00 & 5.00 & 4.04 & 0.914 \\
\hline
\end{tabular}

The evaluation of the professional personality competencies of physical education teachers according the gender of participants is shown in Table 3. While there was a significant difference found for professional enthusiasm and dedication subcomponent for girls, there was a significant difference found in terms of reflective interaction subcomponent for boys $(p<0.05)$. There was no significant difference found for the subcomponent of respect for human dignity and justice $(p>0.05)$. Boys evaluated their physical education teachers as "Partly adequate" in all subcomponents. Girls evaluated respect for human dignity and justice and reflective interaction subcomponents as "Partly adequate", and evaluated the other two subcomponents as “Completely adequate”.

Table 3

Independent Group T-test Results of Subcomponents of PET PPCS-Students According to Gender

\begin{tabular}{|c|c|c|c|c|c|c|}
\hline Professional personality competencies & Gender & $N$ & $M$ & $S D$ & $t$ & $p$ \\
\hline \multirow{2}{*}{ Motivational interaction } & Female & 654 & 4.076 & 0.856 & \multirow{2}{*}{1.981} & \multirow{2}{*}{$0.048^{*}$} \\
\hline & Male & 600 & 3.975 & 0.946 & & \\
\hline \multirow{2}{*}{ Professional enthusiasm and dedication } & Female & 654 & 4.117 & 0.810 & \multirow{2}{*}{2.776} & \multirow{2}{*}{$0.006^{*}$} \\
\hline & Male & 600 & 3.978 & 0.963 & & \\
\hline \multirow{2}{*}{ Human dignity and justice } & Female & 654 & 3.889 & 0.988 & \multirow{2}{*}{1.236} & \multirow{2}{*}{0.216} \\
\hline & Male & 600 & 3.819 & 1.017 & & \\
\hline \multirow{2}{*}{ Reflective interaction } & Female & 654 & 3.108 & 0.835 & \multirow{2}{*}{2.745} & \multirow{2}{*}{$0.006^{*}$} \\
\hline & Male & 600 & 3.966 & 0.989 & & \\
\hline
\end{tabular}

Note. ${ }^{*} p<0.05$.

As a result of the study group’s assessment of professional personality competencies of physical education 
teachers according to school type (state and private), there was a significant difference found in favour of private schools (see Table 4). While high school students studying in state schools evaluated reflective interaction, motivational interaction, and respect for human dignity and justice subcomponents as "Partly adequate", they evaluated professional enthusiasm and dedication subcomponent as "Completely adequate". Students studying in private schools evaluated all their physical education teachers as "Completely adequate" for all subcomponents.

Table 4

Mann-Whitney U-test Results of Subcomponents of PET PPCS-Student According to School Type

\begin{tabular}{|c|c|c|c|c|c|c|}
\hline Professional personality competencies & School type & $N$ & $M$ & $S D$ & $t$ & $p$ \\
\hline \multirow{2}{*}{ Motivational interaction } & State & 1,179 & 3.985 & 0.904 & \multirow{2}{*}{-7.989} & \multirow{2}{*}{$0.000^{*}$} \\
\hline & Public & 75 & 4.694 & 0.525 & & \\
\hline \multirow{2}{*}{ Professional enthusiasm and dedication } & State & 1,179 & 4.013 & 0.891 & \multirow{2}{*}{-7.385} & \multirow{2}{*}{$0.000^{*}$} \\
\hline & Public & 75 & 4.640 & 0.603 & & \\
\hline \multirow{2}{*}{ Human dignity and justice } & State & 1,179 & 3.806 & 1.004 & \multirow{2}{*}{-8.123} & \multirow{2}{*}{$0.000^{*}$} \\
\hline & Public & 75 & 4.640 & 0.556 & & \\
\hline \multirow{2}{*}{ Reflective interaction } & State & 1,179 & 3.997 & 0.918 & \multirow{2}{*}{-7.799} & \multirow{2}{*}{$0.000^{*}$} \\
\hline & Public & 75 & 4.710 & 0.498 & & \\
\hline
\end{tabular}

Note. ${ }^{*} p<0.05$.

Table 5

ANOVA Test Results of Subcomponents of PET PPCS-Student According to Class

\begin{tabular}{|c|c|c|c|c|c|c|}
\hline Professional personality competencies & Class & $N$ & $M$ & $S D$ & $f$ & $p$ \\
\hline \multirow{4}{*}{ Motivational interaction } & 9th class & 415 & 4.129 & 0.873 & \multirow{4}{*}{12.073} & \multirow{4}{*}{$0.000^{*}$} \\
\hline & 10th class & 422 & 4.100 & 0.897 & & \\
\hline & 11th class & 417 & 3.853 & 0.909 & & \\
\hline & Total & 1,254 & 4.027 & 0.901 & & \\
\hline \multirow{4}{*}{ Professional enthusiasm and dedication } & 9th class & 415 & 4.189 & 0.813 & \multirow{4}{*}{13.230} & \multirow{4}{*}{$0.000^{*}$} \\
\hline & 10th class & 422 & 4.081 & 0.943 & & \\
\hline & 11th class & 417 & 3.880 & 0.879 & & \\
\hline & Total & 1,254 & 4.050 & 0.889 & & \\
\hline \multirow{4}{*}{ Human dignity and justice } & 9th class & 415 & 4.013 & 0.879 & \multirow{4}{*}{16.987} & \multirow{4}{*}{$0.000^{*}$} \\
\hline & 10th class & 422 & 3.923 & 1.002 & & \\
\hline & 11th class & 417 & 3.631 & 1.076 & & \\
\hline & Total & 1,254 & 3.855 & 1.002 & & \\
\hline \multirow{4}{*}{ Reflective interaction } & 9th class & 415 & 4.177 & 0.814 & \multirow{4}{*}{13.351} & \multirow{4}{*}{$0.000^{*}$} \\
\hline & 10th class & 422 & 4.082 & 0.953 & & \\
\hline & 11th class & 417 & 3.861 & 0.941 & & \\
\hline & Total & 1,254 & 4.040 & 0.914 & & \\
\hline
\end{tabular}

Note. ${ }^{*} p<0.05$

The results of analysis based on the classes of the research group are shown in Table 5. As a result of analysis made according to classes of the study group, there were significant differences found between 9th, 10th, and 11th graders for all subcomponents of the scale $(p<0.05)$. While the 11th graders evaluated 
professional personality competencies of their physical education teachers as "partly adequate", 9th and 10th graders evaluated it as "Completely adequate”.

\section{Discussion and Conclusion}

As a result of the study group's assessment of scale items, "They care that honesty and trust form the basis of our communication in school" item had the highest average points, while "They do not criticise a student who has negative behaviour in front of the class" had the lowest points on the scale. With these results, it is understood that honesty and trust are the basis of teachers' communication with students. In addition, it is understood that they criticise students who have negative behaviour in front of the class. It is observed that high school students generally evaluated PET PPCS-Student items as "Partly adequate" or "Completely adequate". In research completed by Demir (2012), students gave the highest and the lowest points to the same scale items and evaluated scale items as "Partly adequate" or "Completely adequate". Also, Bilici (2005) found professional personality competencies of physical education teachers working in secondary schools were “Completely adequate”. In research conducted by Kougioumtzis, Patriksson, and Strahlman (2011), "Physical education teachers evaluated themselves as 'Quite adequate' in terms of status and professional competence”. Kaya (2010) obtained the result that "Physical education teachers were 'Adequate' in all competence areas”. As a result of research by Hust, Van Hoecke, De Knop, and Theeboom (2009), it is seen that competencies of physical education teachers are "Adequate". All these results are in line with this research.

As a result of assessment of professional personality competence subcomponents of physical education teachers, while professional enthusiasm and dedication had the highest average points, respect for human dignity and justice had the lowest average points. While the research group evaluated professional enthusiasm and dedication, motivational interaction, and reflective interaction subcomponents as "Completely adequate", they evaluated respect for human dignity subcomponent as "Partly adequate". With this result, it is understood that physical education teachers exhibit behaviour critical to students in front of the class. The same result was also obtained in Demir's (2013) research. In a study made by TED (2009), professional competence of teachers was evaluated as "Adequate”. Chen, Mason, Staniszewski, Upton, and Valley (2012) in their study found that physical education teachers were evaluated as "Adequate". In research by Hacisalihoglu (2006), students evaluated lesson performance of their physical education teachers as "Adequate". Hoffman and Sembiante's (1975) research obtained the result that assessment of justice features, which is one of the professional competence of physical education teachers, was “Adequate”. In Stojanovic and Zdravkovi’s (2012) research, physical education teachers evaluated their professional competence as “Adequate”. In Oksuzoglu's (2009) study, physical education teacher candidates found themselves "Acceptable" in the professional sense. Also, in Sandıkcı and Oncu's (2013) study, physical education teacher candidates found their competencies "Quite high". As a result of qualitative research conducted by Mirzeoolu, Ozcan, and Celebi (2008), it is seen that teacher candidates are "Adequate" in terms of teacher competencies. The results obtained in these studies are consistent with this research.

According to gender of the research group, there are significant differences found between professional personality competencies of physical education teachers in reflective interaction, motivational interaction, and professional enthusiasm and dedication subcomponents. However, there is no difference found in the respect for human dignity and justice subcomponent. While professional personality competencies of physical education teachers were evaluated as "Partly adequate" by boys, girls evaluated motivational interaction and 
professional enthusiasm and dedication subcomponents as "Completely adequate" and evaluated the other two subcomponents as "Partly adequate". Also, in Demir's (2012) study, while there are differences found only for the reflective interaction subcomponent, there was no difference found in other subcomponents. As a result of the study by Safvenbom, Haugen, and Bulie (2014), it was seen that female students exhibit less positive behaviour towards physical education lessons than male students. In Gullu's (2007) research, it was seen that female students have more positive attitudes towards physical education lessons than male students. Also, in Ilkim's (2006) research, there was no significant difference found. In Oksuzoglu's (2009) research, there was no significant difference found in professional competence of physical education teacher candidates according to their gender. However, in Unlu's (2008) research, it was seen in the sense of competence of physical education teachers according to their gender; male teachers feel themselves "More adequate" compared to female colleagues and there were significant differences found according to gender. In studies by Eroglu (2011) and Sandıkcı and Oncu (2013), competencies of physical education teacher candidates did not differ according to gender.

There is a significant difference found between professional personality competencies of physical education teachers according to school type (state or private school) of the study group. Professional competence of physical education teachers was evaluated as "Partly adequate" by high school students studying in state schools. However, high school students studying in private schools evaluated as "completely adequate". With these results, there is a significant difference found in favour of the private schools. It is considered that the reason for this result is that there is only one private school, with enough sport equipment, sport facilities, and sufficient educational staff, included in the study. In Demir's (2012) research, the result was that students studying in private schools have higher averages than students studying in state schools, and so they have more positive attitudes, which supports this research.

There is a significant difference found between professional personality competencies of physical education teachers according to classes of the study group. While 9th graders evaluated professional personality competencies of their physical education teachers as "Completely adequate", 10th graders evaluated respect for human dignity and justice subcomponent as "Partly adequate" and evaluated the other three subcomponents as "Completely adequate". The 11th graders evaluated all subcomponents as "Partly adequate". However, 9th and 10th graders evaluated these as “Completely adequate”. In the study conducted by Gullu (2007), the result that 11th grade students had more negative attitudes towards physical education lessons than 9th and 10th graders supports the results of this research. In Demir's (2012) study, there was a significant difference found between classes.

In conclusion, the results that honesty and trust are the basis of the communication between physical education teachers and students, while teachers also criticise students in front of the class were obtained. It was seen that physical education teachers love their profession and they did not lose enthusiasm. In other words, they have professional enthusiasm and dedication features at "Completely adequate" level according to high school students. However, the result that their respect for human dignity and justice features are at "Partly adequate" levels and they exhibit respect and equal behaviour towards their students at an adequate level were obtained. According to the gender of the study group, there was no difference found for respect for human dignity and justice subcomponent but there were differences found for the other subcomponents. There were significant differences found for professional personality competencies of physical education teachers according to school type and class of students. 


\section{References}

Atencio, M., Jess, M., \& Dewar, K. (2012). It is a case of changing your thought processes, the way you actually teach: Implementing a complex professional learning agenda in Scottish physical education. Physical Education and Sport Pedagogy, 17(2), 127-144.

Bilici, M. (2005). School administrators the ideal is that physical education teachers to investigate and evaluate their expectations (Unpublished master's thesis, Sakarya University).

Buyuknacar, C. (2008). The study of the relationship between emotional competence and professional personality traits of Anatolian and science high school teachers on the basis of students' perceptions: A case study in Gaziantep (Unpublished master's thesis, Gaziantep University).

Camlıca, C. (2008). Students studying in secondary school about physical education lesson ideas and expectations: A case study in Ankara (Unpublished master's thesis, Selcuk University).

Centra, J. A., \& Potteer, D. A. (1980). School and teacher effect: An international model. Review of Education Rresearch, 50(2), 273-291.

Chen, W., Mason, S., Staniszewski, C., Upton, A., \& Valley, M. (2012). Assessing the quality of teacher teaching practise. Educational Assessment Evaluation and Accountabilty, 24, 25-41.

Darling-Hammond, L. (1999). Teacher quality and student achievement: A review of state policy evidence. Washington, D.C.: Stanford University.

Demir, E. (2012). Working in secondary school physical education teachers' professional personality of competence perceptions of assessment (Ph.D. dissertation, Marmara University).

Demir, E. (2013). The professional personality competence of physical education teachers who teach in secondary schools were evaluated of perceived. In Proceedings of The V International Educational Research Congress (pp. 1826-1840). Canakkale: Canakkale Onsekiz Mart University.

Eken, D. (2008). Secondary students' thought and expectations about physical education classes (Unpublished master's thesis, Selcuk University).

Eroglu, B. (2011). Of teaching practice effects candidates of the physical education teachers' professional competence and professional attitudes towards (Ph.D. dissertation, Gazi University).

Gullu, M. (2007). Investigating secondary school students’ attitudes toward physical education classes (Ph.D. dissertation, Gazi University).

Hacisalihoglu, M. (2006). Physical education teachers' of the course performance was evaluated by the students (Unpublished master's thesis, Gazi University).

Hoffman, S. J., \& Sembiante, J. L. (1975). Experience and imagery in movement analysis. In G. J. K. Alderson, \& D. A. Tyldesley (Eds.), British Proceedings of Sports Psychology (pp. 288-293). Salford, U.K.: British Society of Sports Psychology.

Hust, K., Van Hoecke, J., De Knop, P., \& Theeboom, M. (2009). Preliminary analysis of the (process and product) quality of physical education in Flemish secondary schools: Implementation of IKLO. Retrieved September 10, 2012, from http://www.eric.ed.gov/ contentdelivery/servlet/ERICServlet? accno=ED506318

Ilkim, M. (2006). Physical education teachers' according to working conditions to evaluate how they make course to physical education classes (Unpublished master's thesis, Inonu University).

Kaya, K. (2010). Physical education teachers' perceptions of professional competence (Unpublished master’s thesis, Gazi University).

Kougioumtzis, K., Patriksson, G., \& Strahlman, O. (2011). Physical education teachers’ professionalization: A review of occupational power and professional control. European Physical Education Review, 17(1), 111-129.

Lee, V. E., Robinson, S. R., \& Sebastian, J. (2007). The quality of instruction in urban high schools comparing mathematics and science to english and social studies in Chicago. Retrieved September 12, 2012, from http://search.ebscohost.com.onelog. marmara.edu.tr:2048/login.aspx?

Mirzeoolu, D., Ozcan, G., \& Celebi, M. (2008). Physical education teacher candidates analyses of the time management, professional and personality in teaching practise course. In Proceedings of The 10th International Sport Sciences Congress (pp. 124-126). Bolu: Abant Izzet Baysal University.

Monk, D. H. (1994). Subject matter preparation of secondary mathematics and science teachers and student achivement. Economics of Education Review, 13(2), 125-145. 
Oksuzoglu, P. (2009). Physical education teachers’ perceptions of competence for the teaching profession (Unpublished master's thesis, Mersin University).

Pill, S. (2004). Quality learning in physical education. Active \& Healthy Magazine, 11(3), 13-14.

Sacl, F., Bulca, Y., Demirhan, G., \& Kangalgil, M. (2009). Physical education teachers' personal qualities. Journal of Sports Sciences, 20(4), 145-151.

Safvenbom, R., Haugen, T., \& Bulie, M. (2014, April 7). Attitudes toward and motivation for PE: Who collects the benefits of the subject? Physical Education and Sport Pedagogy. doi: 10.1080/17408989.2014.892063

Sandıkcı, M., \& Oncu, E. (2013). Determination and comparison of physical education and the other pre-service teachers' self-efficacy beliefs and attitudes toward teaching profession. Pamukkale Journal of Sport Sciences, 4(1), 135-151.

Sisko, M., \& Demirhan, G. (2002). Elementary and high schools for boys and girls studying attitudes toward in the physical education and sport course. Journal of Education Faculty of Hacettepe University, 23, 205-210.

Stojanovic, S., \& Zdravkovic, D. (2012). The self-assessment of personal competences of physical education teachers. Facta Universitatis Physical Education and Sport, 10(2), 141-149.

Stronge, J. H. (2007). Qualities of effective teachers. Alexandria, V.A.: ASCD.

Tannehil, D., \& Zekrajsek, D. (1993). Student attitudes toward physical education: A multicultural study. Journal of Teaching Physical Education, 13, 78-84.

Turkish Education Association (TED). (2009). Teacher' competences. Ankara: Adım Okan Matbaacılık.

Unlu, H. (2008). Physical education teachers' competencies and classroom management behaviors (Ph.D. dissertation, Gazi University).

Unlu, H., Sunbul, M. A., \& Aydos, L. (2008). Physical education teachers' competence and the validity-reliability study. Journal of Education Faculty of Ahi Evren University, 9(2), 23-33.

Wilson, M. S. (2011). How can we improve teacher quality? Phi Delta Kapan, 93(2), 61-64.

Yaylacı, F. (2012). Quality development problem in physical education course. Bilim ve Aklın Aydınlı̆ğnda Ĕgitim, 13(147), 23-28. 